\title{
PERANAN PROGRAM PELATIHAN DALAM MEMANTAPKAN KOMPETENSI PROFESIONAL GURU SMK TKR
}

\section{THE CONTRIBUTION OF EXPERTISE TRAINING TO STRENGTHEN THE PROFESSIONAL COMPETENCE OF SMK TKR TEACHER}

\author{
Kir Haryana ${ }^{1}$, Nirmala Adhi Yoga Pambayun ${ }^{2}$, Lilik Chaerul Y. ${ }^{3}$, Sukaswanto ${ }^{4}$ \\ Pendidikan Teknik Otomotif FT UNY \\ E-mail: kir_haryana@uny.ac.id
}

\begin{abstract}
ABSTRAK
Tujuan penelitian ini adalah (1) Mengidentifikasi pelatihan keahlian yang diikuti guru; (2) Menganalisis dampak pelatihan; (4) Mengetahui pelatihan yang diinginkan guru; (5) Mengidentifikasi kendala dalam pelatihan keahlian. Penelitian ini menggunakan pendekatan penelitian survey. Populasi penelitian adalah guru paket keahlian TKR di DIY, sampel ditentukan dengan teknik sampling purposive. Instrumen yang digunakan adalah lembar kuesioner dan dokumentasi. Data dianalisis dengan statistik diskriptif. Hasil penelitian menunjukkan, (1) Terdapat 12 jenis pelatihan yang diikuti guru; (2) Dampak pelatihan masuk dalam kategori sangat baik; (3) Pelatihan yang paling diinginkan guru adalah pelatihan Electronic Fuel Injection (EFI); (4) Kendala dalam pelatihan bidang keahlian keduanya masuk dalam kategori rendah
\end{abstract}

Kata Kunci: Pelatihan, Dampak, Kompetensi Profesional

\section{ABSTRACT}

This study aims to, (1) Indentify the expertise training program followed by teacher; ( (3) Analyze the impact of expertise training program; (4) know the expertise training desired by teacher; (5) Identify the obstruction of expertise training program. This study used survey research approach. This study population were teachers of SMK TKR in DIY, purposive sampling technique was used to determine the sample of this study. Data was collected by quisonere and documentation sheets. Data analyzed by discriptive statistic.The result of this study showed that (1) There were 12 kinds of training program followed by teacher; (2) the impact of expertise training is included into very good category; (3) the expertise training program desired by teacher is Electronic Fuel Injection (EFI) training.; (4) The obstruction of expertise training and certification program is included into low obstruction category.

Keyword: Training, Impact, Professional Competence

\section{PENDAHULUAN}

Rencana diberlakukannya Masyarakat Ekonomi ASEAN (MEA) atau ASEAN Economic Community (AEC) di akhir tahun 2015 akan menimbulkan dampak yang sangat luas, baik di bidang ekonomi maupun pendidikan. Masyarakat Ekonomi ASEAN (MEA) adalah bentuk integrasi ekonomi negara-negara ASEAN dalam artian adanya sistem perdagangan bebas di antara negaranegara ASEAN. Indonesia dan sembilan negara anggota ASEAN lainnya telah menyepakati adanya perjanjian Masyarakat Ekonomi ASEAN (MEA) tersebut

Untuk mencapai Masyarakat Ekonomi ASEAN di atas diperlukan AEC Blueprint yang merupakan pedoman bagi negara-negara ASEAN untuk mencapai AEC 2015, yang masing-masing negara berkewajiban melaksanakan komitmen dalam AEC Blueprint tersebut. AEC Blueprint tersebut memuat 4 (empat) pilar utama, (Anonim, t.th.: 9-10), yaitu: (1) ASEAN sebagai pasar tunggal dan 
basis produksi (single market and production base), dengan elemen aliran bebas barang, jasa, investasi, tenaga kerja terdidik dan aliran modal yang lebih bebas, (2) ASEAN sebagai kawasan dengan daya saing ekonomi yang tinggi (competitive economic region), dengan elemen peraturan kompetisi, perlindungan konsumen, hak atas kekayaan intelektual, pengembangan infrastruktur, perpajakan, dan e-commerce, (3) ASEAN sebagai kawasan dengan pengembangan ekonomi yang merata (equitable economic development) dengan elemen pengembangan usaha kecil dan menengah dan prakarsa integrasi ASEAN untuk negara CMLV (Cambodia, Myanmar, Laos, dan Vietnam), dan (4) ASEAN sebagai kawasan terintegrasi secara penuh dengan perekonomian global (integration into the global economy) dengan elemen pendekatan yang koheren dalam hubungan ekonomi di luar kawasan, dan meningkatkan peran serta dalam jejaring produksi global. Pada saat ini pilar yang pertama menjadi perhatian utama ASEAN.

Untuk mewujudkan AEC pada tahun 2015, seluruh negara ASEAN harus melakukan liberalisasi: (1) arus bebas barang, (2) arus bebas jasa, (3) arus bebas investasi, (4) arus modal yang lebih bebas, dan (5) arus bebas tenaga kerja terampil (Anonim, t.th.: 18 - 41). Yang dimaksud dengan liberalisasi dalam hal ini adalah arus masuk atau arus keluar barang, jasa, investasi, modal, dan tenaga kerja di antara negara-negara anggota ASEAN termasuk Indonesia.

Berbagai peluang dan tantangan akan dihadapi oleh bangsa Indonesia dengan diberlakukannya MEA di tahun 2015 tersebut. Salah satu tantangan adalah daya saing sumber daya manusia (SDM) (Anonim, t.th.: 80). Kemampuan bersaing SDM tenaga kerja Indonesia harus ditingkatkan baik secara formal maupun informal. Untuk menuju hal tersebut, Indonesia harus dapat meningkatkan kualitas tenaga kerjanya sehingga bisa digunakan baik di dalam negeri maupun maupun intra-ASEAN untuk mencegah membanjirnya tenaga kerja terampil dari luar. Pekerjaan ini memerlukan sebuah sistem pendidikan yang menyeluruh dan sertifikasi berbagai profesi.

Salah satu sistem pendidikan yang diperlukan dalam menghadapi MEA adalah SMK Teknik Kendaraan Ringan (TKR) yang bertugas menyiapkan calon tenaga kerja tingkat menengah yang bekerja di industri perawatan dan perbaikan kendaraan bermotor. Tenaga kerja menengah dalam bidang perawatan dan perbaikan otomotif yang terampil dan terdidik diperlukan untuk memenuhi daya saing tenaga kerja di negara-negara anggota ASEAN.

Peran guru SMK sangat penting dan strategis bagi pendidikan di SMK yang mempunyai tujuan menyiapkan tenaga kerja yang mampu bersaing dengan tenaga kerja dari negara anggota ASEAN. Sebagai calon tenaga kerja yang akan bersaing dengan tenaga kerja lain di negara-negara anggota ASEAN, maka lulusan SMK seharusnya memiliki kompetensi yang standar MEA. Oleh karena itu lulusan SMK harus mempunyai kompetensi yang tersertifikasi (certified) yang diuji dan diakui oleh industri-industri di negara ASEAN.

Implikasinya dari lulusan SMK yang tersertifikasi kompetensinya tersebut maka guru-guru di SMK juga seharusnya memiliki kompetensi dan sertifikat keahlian dalam bidangnya. Dengan demikian bila lulusan SMK TKR sudah mengalami uji kompetensi dan memiliki sertifikat yang dikeluarkan oleh industri otomotif atau LSP yang didukung industri otomotif, maka guru SMK TKR seharusnya juga memiliki kompetensi (produktif) dan memiliki sertifikat keahlian yang dikeluarkan oleh industri.

Kompetensi guru menurut Undangundang Nomor 14 Tahun 2005 tentang Guru dan Dosen, adalah kompetensi pedagogis, kompetensi profesional, kompetensi kepribadian, dan kompetensi sosial. Empat kompetensi yang dijelaskan di atas harus dimiliki oleh guru dalam menjalankan tugas sebagai guru. Dari empat kompetensi yang diuraikan di atas, maka dalam penelitian ini dibatasi pada kompetensi profesional karena mempunyai keterkaitan yang erat dengan bidang materi keilmuan. Dalam hal ini 
kompetensi profesional mempunyai keterkaitan yang erat dengan bidang materi keilmuan teknik kendaraan ringan atau teknik otomotif.

Untuk mendalami dan meningkatkan kompetensi profesional yang pernah diperoleh selama pendidikan di LPTK, para guru SMK TKR dalam menjalankan tugasnya mengikuti berbagai program secara individual ataupun secara bersama. Secara individual, guru SMK TKR mendalami kompetensi profesional dengan cara berlatih sendiri dengan bahan pembelajaran dengan uji coba terhadap training obyek pembelajaran. Secara kelompok, melalui agenda kegiatan kelompok guru sejenis (MGMP) melakukan kegiatan praktik keahlian bidang teknik otomotif dengan bekerjasama dengan instansi lain, misalnya LPTK, LSP atau industri. Bagi guru yang pernah mengikuti pelatihan dan memperoleh sertifikat keahlian tertentu, menularkan pengalamnnya pada sejawat guru dengan pelatihan di sekolah sendiri (in-house training). Selain itu juga sudah banyak para guru yang mengikuti uji kompetensi yang dilakukan oleh asosiasi profesi atau asosiasi uji kompetensi, dalam rangka memperoleh sertifikat asesor. Beberapa industri otomotif dalam rangka tanggungjawab sosial (corporate social responsibility $=C S R$ ) melakukan pelatihan mengenai teknologi baru terhadap para guru SMK TKR. Meskipun setelah pelatihan guru memperoleh sertifikat, namun demikian masih belum banyak guru yang memperoleh sertifikat keahlian yang dikeluarkan oleh industri atau lembaga sertifikat profesi.

Menurut Mustaghfirin Amien, salah satu Program Direktorat Pembinaan SMK Tahun 2015 - 2019 adalah peningkatan mutu SMK, yaitu: (1) Pengembangan kelembagaan SMK, (2) Ranah garap yang ditangani SMK, (3) Membangun partnership antara sekolah dengan dunia bisnis, (4) Pengembangan fasilitas pendidikan SMK, (5) Meningkatkan kualitas guru kejuruan. Khusus untuk meningkatkan kualitas guru kejuruan dilakukan dengan: (a) melatih "guru dengan double kompetensi"; (b) memberlakukan peraturan keharusan praktik pengalaman kerja bagi guru SMK; (c) mendampingi SMK dalam penyempurnaan sistem kepegawaian di sekolah sehingga dapat mempekerjakan guru ahli yang berpengalaman kerja agar bisa mengajar di SMK sebagai guru tamu paruh waktu.

Pertanyaannya adalah bagaimanakah pelaksanaan program peningkatan mutu guru SMK TKR melalui pelatihan keahlian di bidang teknik otomotif? Seberapa jauh program pelatihan tersebut telah diikuti oleh para guru SMK TKR? Bagaimanakah peranan pelatihan keahlian tersebut dalam memantapkan kompetensi profesional guru di bidang teknik otomotif?

\section{Kompetensi Profesional Guru}

McAshan (1979:38) menyatakan bahwa: "competence represent the cognitive, affective, and psychomotor learning outcomes established for or by the learner." Selanjutnya McAshan (1979: 45) menyatakan bahwa kompetensi adalah: “....the knowledge, skills, and abilities or capabilities that a person achieves, which become part of his or her being to the extent he or she can satisfactory perform particular cognitive, affective, and psychomotor behaviors. They represent the instructional intents of a program and are stated as specific goals to be achieved".

Dalam Undang-undang Nomor 14 Tahun 2005 tentang Guru dan Dosen pada Bab IV pasal IV pasal 10 ayat (1) dinyatakan bahwa: "Kompetensi guru sebagaimana dimaksud dalam Pasal 8 meliputi kompetensi pedagogik, kompetensi kepribadian, kompetensi sosial, dan kompetensi profesional yang diperoleh melalui pendidikan profesi”. Pada Bab I pasal 1 ayat (4) dikatakan bahwa:" profesional adalah pekerjaan atau kegiatan yang dilakukan oleh seseorang dan menjadi sumber penghasilan kehidupan yang memerlukan keahlian, kemahiran, atau kecakapan yang memenuhi standar mutu atau norma tertentu serta memerlukan pendidikan profesi". Dengan demikian berdasarkan Undang-undang No 14 Tahun 2005 tentang Guru dan Dosen Bab I ayat (4) tersebut bahwa profesional adalah: 
pekerjaan yang dilakukan seseorang, (2) pekerjaan yang menjadi sumber penghasilan kehidupan, (3) pekerjaan yang memerlukan keahlian, kemahiran, atau kecakapan, (4) pekerjaan yang memenuhi standar mutu atau norma tertentu, dan (5) memerlukan pendidikan tertentu.

Wirawan (2002: 11-18) menyatakan bahwa agar suatu pekerjaan dapat menjadi profesi diperlukan persyaratan tertentu, antara lain: (1) Pekerjaan penuh, yang artinya bukan pekerjaan paruh waktu, (2) Bidang pekerjaan berdasarkan Ilmu Pengetahuan tertentu, (3) Pekerjaan tersebut merupakan aplikasi Ilmu Pengetahuan, (4) terdapat Lembaga Pendidikan Profesi yang berkaitan dengan pekerjaan tersebut, (5) ada Perilaku Profesional yang dibakukan, (6) terdapat Standar tertentu dari Profesi tersebut, (7)mempunyai Asosiasi Profesi, dan (8) mempunyai Kode Etik Profesi.

Berdasarkan uraian di atas maka guru SMK TKR termasuk sebagai suatu profesi, karena guru tersebut lulusan pendidikan bidang keguruan, dan diharuskan memiliki keahlian, kemahiran, atau kecakapan tertentu yang memenuhi standar mutu tertentu. Oleh karena itu guru SMK TKR diwajibkan memiliki kompetensi profesional yang diakui pada standar mutu tertentu.

Kompetensi profesional guru adalah kedalaman penguasaan materi bidang studi yang telah dimiliki untuk mendukung terlaksananya pembelajaran yang optimal. Dalam Permendiknas Nomor 16 Tahun 2007 tentang Standar Kualifikasi Akademik dan Kompetensi Guru disebutkan bahwa kompetensi profesional pada Kompetensi Inti Guru adalah: (1) Menguasai materi, struktur, konsep, dan pola pikir keilmuan yang mendukung mata pelajaran yang diampu, (2) Menguasai standar kompetensi dan kompetensi dasar mata pelajaran yang diampu, (3) Mengembangkan materi pembelajaran yang diampu secara kreatif, (4) Mengembangkan keprofesionalan secara berkelanjutan dengan melakukan tindakan reflektif, dan Memanfaatkan teknologi informasi dan komunikasi untuk mengembangkan diri.
Dengan pelatihan dan sertifikasi keahlian di bidang teknik otomotif, diharapkan guru SMK TKR dapat mencapai kompetensi profesional yang diharapkan.

Menurut Suyanto (2007: 3-4) yang mengutip pendapat Houle, bahwa secara akademik agar seorang guru menjadi profesional, maka dia harus memiliki beberapa ciri atau karakteristik, yaitu: (1) harus memiliki landasan pengetahuan yang kuat; (2) harus berdasarkan atas kompetensi individual; (3) memiliki sistem seleksi dan sertifikasi; (4) ada kerjasama dan kompetisi yang sehat antar sejawat; (5) ada kesadaran profesional yang tinggi; (6) memiliki prinsip-prinsip etik (kode etik); (7) memiliki sistem sanksi profesi; (8) adanya militansi individual; dan (9) memiliki organisasi profesi.

Guru SMK TKR yang memiliki kompetensi profesional akan menguasai materi keilmuan yang menjadi bidang tugasnya, dan mampu mengembangkan materi keilmuan tersebut secara kreatif dalam pekerjaannya sebagai guru dengan menggunakan fasilitas teknologi informasi dan komunikasi. Di samping itu, kompetensi yang berupa keahlian, kemahiran, dan kecakapan tersebut sesuai dengan standar mutu melalui sertifikasi yang ditetapkan oleh industri dan asosiasi profesi.

\section{Pelatihan Keahlian}

Kompetensi guru SMK TKR perlu selalu ditingkatkan sesuai dengan perkembangan teknologi di bidang otomotif. Teknologi di bidang otomotif berkembang dengan pesat, sehingga guru harus dapat mengikuti perkembangan yang ada. Peningkatan kompetensi guru salah satunya dapat dilakukan melalui pelatihan.

Jacobs (2003: 4) menyatakan bahwa : “ ...training is ultimately about the issue of developing high levels of employee competence, or exspertise. Expertise is what experts know and can do. Experts are the individuals who are the most capable in specific areas of human endeavor". Menurut Jacobs di atas, pelatihan bertujuan agar pekerja mencapai kompetensi yang tinggi, atau memiliki keahlian. 
Keahlian adalah sesuatu yang diketahui dan dikerjakan oleh ahli. Ahli adalah orang yang paling mampu dalam kehidupan manusia.

Orang yang memiliki tingkat kompetensi paling tinggi disebut ahli. Menurut Jacobs dan Washington dalam Jacobs (2003: 5), kompetensi (human competence) digolongkan ke dalam rentang taksonomi dari tingkat pemula (novice) yang rendah sampai pada tingkat keahlian yang paling tinggi (master). Kategori tingkat kompetensi tersebut adalah: (1) pemula (novice), (2) spesialis (specialist), (3) spesialis berpengalaman (experienced specialist), (4) ahli (expert), dan (5) ahli tertinggi (master).

Kompetensi dapat dikembangkan melalui pelatihan. Pelatihan adalah alat yang digunakan oleh suatu organisasi untuk mengembangkan kompetensi pekerja pada tingkat yang diinginkan. Pelatihan dan kompetensi tersebut berjalan seiring (go hand in hand). Apakah seorang menginginkan menjadi seorang ahli atau seorang spesialis untuk memenuhi harapannya, maka pelatihan merupakan alat untuk mencapainya.

Jacobs (2003: 13) membedakan pelatihan menjadi 2 (dua) bedasarkan tempat pelaksanaannya, yaitu: pelatihan di luar tempat kerja (off the job training) dan pelatihan di dekat atau di tempat kerja (on the job training). Off the job trainingdapat dilaksanakan di dalam suatu kelas pelatihan di luar yang di dekat tempat pekerjaan yaitu dengan fasilitas yang disediakan untuk pelatihan, atau suatu fasilitas swasta yang jauh dari tempat kerja. On the job training (OJT) dilakukanatau terjadi di tempat kerja atau paling tidak sedekat mungkin dengan tempat kerja.

Sertifikasi yang selama ini memang sudah dilaksanakan untuk para guru termasuk guru SMK TKR. Sertifikasi tersebut merupakan amanat Undang-undang Nomor 14 Tahun 2005 tentang Guru dan Dosen. Untuk melakukan sertifikasi ini dilakukan melalui pendidikan dan pelatihan profesi guru (PPG) agar diperoleh kompetensi dan sertifikat profesi guru. Meskipun diharapkan guru akan memperoleh kompetensi (pedagogis, profesional, pribadi, dan sosial), namun faktanya menunjukkan bahwa kompetensi profesional para guru SMK TKR masih harus ditingkatkan. Oleh karena itu program pelatihan keahlian di bidang teknik otomotif harus menjadi agenda utama pemerintah dalam rangka meningkatkan mutu guru SMK TKR pada khususnya dan mutu SMK pada umumnya.

\section{METODE PENELITIAN}

Jenis Penelitian

Penelitian ini menggunakan pendekatan penelitian survey.

Populasi dan Sampel

Populasi penelitian ini adalah semua guru SMK Teknik Kendaraan Ringan di Daerah Istimewa Yogyakarta yang tersebar di semua SMK yang memiliki paket keahlian Teknik Kendaraan Ringan.

Teknik sampling yang digunakan pada penelitian ini adalah teknik purposive karena yang dipilih adalah dari SMK Negeri di tiap kabupaten/kota saja, dengan pertimbangan bahwa para guru di SMK Negeri lebih banyak memiliki kesempatan mengikuti program pelatihan bidang keahlian. Jumlah sampel yang dipilih adalah 30 guru yang sudah mengikuti pelatihan bidang keahlian.

Teknik dan Instrumen Pengumpulan Data

Teknik pengumpulan data pada penelitian ini menggunakan metode angket dan dokumentasi. Instrumen yang digunakan adalah lembar kuesioner dan lembar dokumentasi.

Teknik Analisis Data

Data penelitian tentang peranan program pelatihan keahlian bidang teknik otomotif pada guru SMK TKR di DIY ini akan dianalisis dengan metode analisis deskriptif kuantitatif yang berbentuk persentase, dan analisis deskriptif kualitatif berbentuk uraian verbal.

Berdasarkan adaptasi pendapat dari Mardapi (2008: 122-123), data pada aspek dampak dan kendala pelatihan bidang keahlian 
dikelompokkan berdasarkan pengkategorian seperti tertera pada tabel di bawah.

Tabel 1. Kriteria Dampak dan Kendala pada Pelatihan Bidang Keahlian

\begin{tabular}{lll}
\hline \multicolumn{1}{c}{ Interval Nilai } & \multicolumn{1}{c}{ Kategori Dampak } & \multicolumn{1}{c}{ Kategori Kendala } \\
\hline Skor $>\mathrm{Mi}+1,5 \mathrm{SDi}$ & Sangat baik & Sangat Rendah \\
$\mathrm{Mi} \leq \mathrm{Skor}<\mathrm{Mi}+1,5 \mathrm{SDi}$ & Baik & Rendah \\
$\mathrm{Mi}-1,5 \mathrm{SDi} \leq \mathrm{Skor}<\mathrm{Mi}$ & Rendah & Tinggi \\
Skor $<\mathrm{Mi}-1,5 \mathrm{SDi}$ & Sangat rendah & Sangat Tinggi \\
\hline
\end{tabular}

Keterangan:

$\mathrm{Mi}=1 / 2$ (skor ideal maksimum + skor ideal minimum)

$\mathrm{SDi}=1 / 6$ (skor ideal maksimum - skor ideal minimum)

\section{HASIL PENELITIAN DAN PEMBAHASAN}

Program Pelatihan Keahlian Bidang Teknik Otomotif yang Diikuti Guru SMK TKR

Kompetensi guru SMK khususnya pada bidang Teknik Kendaraan Ringan harus selalu ditingkatkan karena perkembangan teknologi pada bidang ini berkembang dengan sangat cepat. Oleh karena itu diperlukan pelatihan, untuk dapat selalu meng-upgrade atau meningkatkan kompetensi guru. Idealnya setiap guru secara periodik mendapatkan pelatihan pada bidang yang diajarnya, sehingga guru dapat berkembang dan kualitas mengajarnya dapat ditingkatkan. Berdasarkan hasil penelitian, pelatihan yang diikuti oleh guru TKR di DIY diantaranya dapat dilihat pada tabel 2 di bawah.

Berdasarkan data yang disajikan pada tabel 2, jenis pelatihan yang diikuti oleh guru dapat dikelompokkan menjadi 12 kelompok. Dimana pada data ini satu guru bisa mendapatkan lebih dari satu jenis pelatihan. Berdasarkan hasil penelitian penyelenggara pelatihan dapat berasal dari instansi pemerintah, organisasi guru, instansi pendidikan dan pelatihan, perguruan tinggi dan industri. Dimana dari data di atas, unsur dari industri yang paling banyak menyelenggarakan pelatihan.

Apabila diamati dari jenis pelatihannya, ternyata terdapat guru TKR yang mendapatkan pelatihan yang berkaitan dengan paket keahlian lain seperti sepeda motor dan bodi kendaraan. Dimana jenis pelatihan yang paling banyak sudah diikuti oleh guru adalah yang berkaitan dengan ilmu umum otomotif yang diikuti oleh $67 \%$ guru. Untuk jenis pelatihan yang spesifik pada bagian atau teknologi tertentu pada TKR yang paling banyak diikuti oleh guru adalah pelatihan tentang teknologi EFI.

Sebagaimana dijelaskan sebelumnya bahwa dari jenis pelatihannya, terdapat guru TKR yang mendapatkan pelatihan yang berkaitan dengan paket keahlian lain, yaitu seperti sepeda motor dan bodi kendaraan. Pada hal, kedua bidang ini tidak ada hubungannya dengan TKR secara umum atau bukan merupakan bidang-bidang kompetensi yang harus dikuasai guru TKR. Berdasarkan kondisi demikian, maka menunjukkan bahwa: (a) Terdapat kekurangjelasan tentang sistem pelatihan bagi guru-guru TKR, yang semestinya sudah jelas tertuang dalam tujuan dan sasaran program; (b) Prosedur dan pelaksanaan pelatihan yang kurang memperhatikan latar belakang bidang profesi atau kompetensi guru, dan yag utama kurang memperhatikan bidang ajar guru, yaitu TKR; (c) Kurang memberikan semangat kepada para guru pada saat pelatihan, karena dampak atau tindak lanjut setelah di sekolah tidak ada atau tidak mendukung dengan tugasnya; (d) Hasil pelatihan secara kebijakan adalah sia-sia, tidak efisien, dan tidak relevan dengan bidang TKR. 
Dimana jenis pelatihan yang paling banyak sudah diikuti oleh guru adalah yang berkaitan dengan ilmu umum otomotif yang diikuti oleh $67 \%$ guru. Melihat hasil ini menggambarkan bahwa proporsi ilmu umum otomotif masih menjadi dominan atau pilihan guru yang paling banyak menarik atau justru kurang pemahamannya. Jika ternyata karena kurang pemahaman, maka dapat dimaknai adalah: (a) Pada saat belajar di perguruan tinggi belum memiliki kompetensi yang sesuai dengan kebutuhan lapangan, yaitu tuntutan kurikulum SMK. Jika melihat hasil-hasil secara nasional dalam uji kompetensi yang masih rendah, maka dapat diartikan bahwa guru-guru TKR dalam penguasaan ilmu ini memang juga rendah (benar adanya); (b) Kondisi ini juga bisa disebabkan pada pilihan menu atau materi tatar yang tidak relevan (didominasi oleh ilmu umum otomotip), sehingga guru dipaksa untuk mengikuti yang ada; (c) Ragam spektrum dan bidang-bidang otomotip yang cakupannya sangat luas, sehingga berlaku pendekatan berbasis luas yang berakibat pada pemilihan ilmu umum; (d) Ketidaksesuaian antara arah kebijakan pendidikan di SMK secara nasional dengan kondisi lapangan, baik sekolah maupun tuntutan masyarakat/dunia usaha/industri.

Tabel 2. Jenis Pelatihan yang diikuti oleh Guru SMK TKR

\begin{tabular}{clc}
\hline No & \multicolumn{1}{c}{ Jenis Pelatihan } & Persentase (\%) \\
\hline 1 & EFI & 33 \\
2 & Common Rail & 23 \\
3 & Sistem Kemudi, Rem dan Suspensi & 17 \\
4 & Sepeda Motor & 7 \\
5 & K3 & 10 \\
6 & Manajemen Bengkel & 7 \\
7 & AC & 10 \\
8 & Engine Management System & 3 \\
9 & Perbaikan Bodi Kendaraan & 23 \\
10 & Pelatihan alat uji & 17 \\
11 & Pelatihan asesor uji kompetensi guru & 27 \\
12 & Umum otomotif & 67 \\
\hline
\end{tabular}

Sedangkan untuk jenis pelatihan yang spesifik pada bagian atau teknologi tertentu pada TKR yang paling banyak diikuti oleh guru adalah tentang teknologi EFI. Beberapa hal yang dapat menyebabkan kondisi ini adalah: (1) Bidang ini merupakan salah satu bidang yang kemanjuan teknologinya sangat cepat, sehingga kondisi di lapangan sudah ada sementara dalam dunia pendidikan masih terbatas pembahasannya; (2) Kurikulum setingkat SMK belum mencakup banyak hal dalam teknologi ini serta belum mendalam pembelajarannya, sehingga para guru banyak yang belum menguasai; (3) Demikian juga saat belajar di perguruan tinggi, materi yang diterima sudah ketinggalan jaman, sehingga menuntut guru untuk mampu mengikutinya, karena di kurikulum SMK serta lapangan sudah menuntut dalam batas tertentu.
Berdasarkan hasil penelitian juga dapat diketahui bahwa masih terdapat bidang pada teknik kendaraan ringan yang belum terakomodasi seperti pada bidang sistem pemindah tenaga. Oleh karena itu perlu adanya pemetaan untuk pelatihan yang diberikan kepada guru sehingga guru mendapatkan pelatihan sesuai dengan bidang keahliannya dan seluruh guru yang membutuhkan mendapatkan pelatihan. Upaya ini harus dilakukan untuk menyediakan guru yang kompeten pada bidangnya.

Dampak Program Pelatihan Keahlian Bidang Teknik Otomotif terhadap Kemantapan Kompetensi Profesional pada Guru SMK Paket Keahlian Teknik Kendaraan Ringan

Pelatihan bidang keahlian diharapkan dapat memberikan dampak yang baik terhadap 
kompetensi dan aspek lain dari guru. Berdasarkan hasil penelitian yang disajikan pada tabel 4, dampak dari dilaksanakannya pelatihan bidang keahlian bidang teknik otomotif terhadap kemantapan kompetensi profesional pada guru SMK paket keahlian teknik kendaraan ringan secara umum masuk dalam kategori sangat baik.

Dimana skor tertinggi diperoleh pada aspek peningkatan kepercayaan diri dalam mengajar dengan 117 dan terendah pada peningkatan karir dalam pekerjaan dengan skor 88. Hal ini menunjukkan bahwa dampak dengan dilakukannya pelatihan belum secara optimal mendukung peningkatan karir dari guru.

Indikator-indikator yang dapat dilihat dari peningkatan pada bidang-bidang otomotip antaralain adalah: (a) Penguasaan materi pembelajaran; (b) Perluasan pendekatan pembelajaran; (c) Keragaman penilaian hasil belajar; (d) Pemanfaatan media pembelajaran; (e) Pemanfaatan TIK dalam pembelajaran dan penilaian hasil belajar; (f) Secara psikologis mampu mengembangkan kreativitas, inovasi, refleksi, dan motivasi berprestasi.

Dampak dari pelatihan terhadap berbagai bidang tersebut sangat membantu sekolah dalam upaya peningkatan mutu pendidikan, khususnya mutu lulusan SMK. Namun demikian, banyak hal yang belum dapat dicapai sebagai suaatu dampak pelatihan sebagaimana tujuan peningkatan kompetensi guru pada umumnya, yaitu kepribadian, sosial, profesional, dan pedagodik. Secara khusus belum menyentuh kepada kompetensi kepribadian yang memiliki dampak tersendiri. Pada hal, justru faktor kepribadian inilah yang utama dan melandasi sebagai guru yang profesional. Perubahan mindset guru lebih penting daripada penguasaan materi. Sebab, dengan berdampak terjadinya perubahan cara pandang guru sesuai perkembangan jaman ini akan memberikan dampak lanjutan terhadap jiwa kemandirian, tanggungjawab, dedikasi, dan rela berkorban demi anak didik, bangsa dan negaranya.

Tabel 3. Dampak Program Pelatihan Keahlian Bidang Teknik Otomotif

\begin{tabular}{|c|c|c|c|}
\hline No & Indikator Dampak Pelatihan & Skor & Kategori Dampak \\
\hline 1 & $\begin{array}{l}\text { Peningkatan penguasaaan materi keilmuan (pengetahuan) dari mata } \\
\text { pelajaran yang diampu. }\end{array}$ & 115 & Sangat Baik \\
\hline 2 & $\begin{array}{l}\text { Peningkatan penguasaaan keterampilan pada mata pelajaran yang } \\
\text { diampu. }\end{array}$ & 104 & Sangat Baik \\
\hline 3 & $\begin{array}{l}\text { Peningkatan kepercayaan diri dalam mengajar setelah mendapatkan } \\
\text { pelatihan. }\end{array}$ & 117 & Sangat Baik \\
\hline 4 & $\begin{array}{l}\text { Peningkatan kemampuan mengatasi masalah dalam pembelajaran } \\
\text { setelah mendapatkan pelatihan. }\end{array}$ & 106 & Sangat Baik \\
\hline 5 & Peningkatan kreativitas dalam melaksanakan proses pembelajaran . & 109 & Sangat Baik \\
\hline 6 & Peningkatan kreativitas dalam mengembangkan materi ajar. & 112 & Sangat Baik \\
\hline 7 & $\begin{array}{l}\text { Peningkatan kemampuan melakukan refleksi pembelajaran untuk } \\
\text { menciptakan inovasi dalam rangka meningkatkan kualitas } \\
\text { pembelajaran. }\end{array}$ & 101 & Sangat Baik \\
\hline 8 & $\begin{array}{l}\text { Peningkatan motivasi untuk meng-updet pengetahuan dalam rangka } \\
\text { pengembangan diri. }\end{array}$ & 112 & Sangat Baik \\
\hline 9 & $\begin{array}{l}\text { Peningkatan motivasi untuk meningkatkan keterampilan dalam rangka } \\
\text { pengembangan diri. }\end{array}$ & 115 & Sangat Baik \\
\hline 10 & $\begin{array}{l}\text { Peningkatan kemampuan dalam menggunakan teknologi informasi } \\
\text { dan komunikasi untuk mengembangkan diri. }\end{array}$ & 103 & Sangat Baik \\
\hline 11 & $\begin{array}{l}\text { Peningkatan pemanfaatan teknologi informasi dan komunikasi untuk } \\
\text { peningkatan kualitas pembelajaran. }\end{array}$ & 107 & Sangat Baik \\
\hline 12 & $\begin{array}{l}\text { Peningkatan pemanfaatan teknologi informasi dan komunikasi untuk } \\
\text { pengembangan karir. }\end{array}$ & 100 & Sangat Baik \\
\hline 13 & Peningkatan karir dalam pekerjaan setelah mendapatkan pelatihan. & 88 & Baik \\
\hline & Rata-Rata & 106.85 & Sangat Baik \\
\hline
\end{tabular}


Pelatihan Keahlian Bidang Teknik Otomotif yang Diinginkan Guru SMK TKR

Bidang teknik otomotif khususnya pada teknik kendaraan ringan dapat dikelompokkan pada beberapa bagian/aspek teknologi diantaranya adalah teknologi motor bensin, teknologi motor diesel, sistem kemudi, rem dan suspensi, sistem pemindah tenaga dan sistem kelistrikan. Sebagai guru di SMK khususnya pada paket keahlian teknik kendaraan ringan, maka guru akan mengajarkan salah satu atau lebih bagian/aspek teknologi tersebut kepada siswa. Oleh karena teknologi selalu berkembang, maka guru menginginkan mendapatkan pelatihan untuk dapat kompeten dalam mengajar dan mendidik siswa pada bidang yang diajarkan.

Untuk mengumpulkan data tentang pelatihan yang diinginkan guru maka digunakan pertanyaan terbuka beserta alasannya. Pelatihan yang diinginkan oleh guru pada bagian/aspek teknologi dari teknik kendaraan ringan disajikan pada tabel 6 .

Apabila diamati dari jenis pelatihan yang diinginkan oleh guru, ternyata dari kelima bidang yang ada pada bidang teknik kendaraan ringan hampir keseluruhan merupakan teknologi baru yang diaplikasikan pada kendaraan-kendaraan terbaru dan tingkat kesulitannya cukup tinggi. Selain itu apabila dicermati dari alasan yang disampaikan oleh responden didapat alasan paling banyak adalah guru belum menguasai.

Berdasarkan pembahasan tersebut dapat diketahui bahwa diperlukan pelatihan-pelatihan pada teknologi-teknologi terbaru yang diaplikasikan pada kendaraan ringan. Terutama pada teknologi-teknologi yang masuk dalam kurikulum pembelajaran di SMK paket keahlian teknik kendaraan ringan. Sehingga nantinya didapatkan pembelajaran yang responsif terhadap kemajuan teknologi pada bidang otomotif khususnya pada paket keahlian teknik kendaraan ringan.

Untuk mewujudkan hal tersebut diperlukan kesadaran dari guru sendiri untuk selalu meng-upgrade kemampuannya baik melalui belajar secara mandiri, belajar bersama melalui MGMP masing-masing mapel dan mampu memanfaatkan peluang dari adanya program-program pelatihan baik dari perguruan tinggi maupun industri. Selain itu juga perlu adanya tindakan tanggap dari dinas pendidikan dan kementrian pendidikan khususnya pada pendidikan menengah kejuruan untuk selalu menyediakan fasilitas pada bidang pelatihan untuk meningkatkan kualitas guru.

Tabel 4. Pelatihan Bidang Keahlian yang diinginkan Guru

\begin{tabular}{clccl}
\hline No & $\begin{array}{c}\text { Pelatihan Bidang Keahlian Diinginkan } \\
\text { Guru }\end{array}$ & $\begin{array}{c}\text { Jumlah } \\
\text { Guru }\end{array}$ & $\begin{array}{c}\text { Persentase } \\
(\%)\end{array}$ & Alasan \\
\hline 1 & Electronic Fuel Injection (EFI) & 21 & 70 & a. Belum menguasai \\
2 & Teknologi Common Rail & 26 & 87 & b. Upgrade kompetensi \\
3 & Elektronik Power Steering (EPS) & 20 & 67 & c. Kompetensi \\
4 & Transmisi otomatis & 23 & 77 & dibutuhkan dilapangan \\
5 & Sistem kelistrikan bodi secara & & & \\
\hline
\end{tabular}

Kendala-kendala Guru SMK TKR dalam Program Pelatihan Keahlian Bidang Teknik Otomotif yang Diikuti

Kendala yang dialami guru dalam pelatihan bidang keahlian pada penelitian ini ditinjau dari aspek internal dan eksternal. Aspek internal berkaitan dengan motivasi dari guru dan ketersediaan dana pribadi, sedangkan aspek eksternal ditinjau dari pelaksanaan program pelatihan, kesempatan guru mendapatkan pelatihan dan dana pelatihan, kesibukan guru di sekolah dan di luar sekolah, dan dorongan dari 
sekolah untuk mengikuti pelatihan. Hasil penelitian disajikan pada tabel 8 di bawah.

Dimana dalam aspek ini item indikator yang semakin tinggi skornya maka kendalanya semakin rendah dan sebaliknya. Berdasarkan data yang disajikan pada tabel 8 , secara umum kendala dalam pelatihan bidang keahlian masuk dalam kategori kendalanya rendah dengan skor 78,2. Apabila dilihat dari masing-masing aspek, dapat diketahui bahwa kendala pada pelatihan bidang keahlian paling rendah berada pada aspek kesesuaian isi pelatihan terhadap bidang keahlian guru dengan skor paling tinggi yaitu 97. Aspek yang paling tinggi mengalami kendala adalah pada kesempatan mendapatkan pelatihan melalui program yang diselenggarakan oleh perguruan tinggi dengan skor 59. Namun demikian, terdapat beberapa aspek lainnya yang masuk kedalam kategori mengalami kendala yang tinggi yaitu diantaranya pada aspek: 1) Kesibukan di sekolah mengganggu proses pelatihan; 2) Ketersediaan dana untuk mengikuti pelatihan; 3) Kesempatan mendapatkan pelatihan melalui program sekolah; 4) Kesempatan mendapatkan pelatihan melalui program dinas atau pemerintah; 5) Kesempatan mendapatkan pelatihan melalui program yang diselenggarakan oleh industri atau swasta.

Oleh karena itu perlu adanya upaya untuk mengurangi kendala yang terjadi yaitu 1) dengan memperbesar kesempatan guru untuk mendapatkan pelatihan baik melalui program dari perguruan tinggi, sekolah dan instansi pemerintah yang terkait lainnya, serta dari pihak industri; 2) pemberian tugas kepada guru yang proporsional disekolah sehingga guru memiliki waktu dan kesempatan untuk mengembangkan diri; 3) memperbesar alokasi dana untuk pengembangan kompetensi guru.

Tabel 5. Kendala Pelatihan Bidang Keahlian

\begin{tabular}{|c|c|c|c|}
\hline No & Indikator Kendala Pelatihan Bidang Keahlian & Skor & Kategori Kendala \\
\hline 1 & Variasi jenis pelatihan dalam bidang keahlian. & 82 & Rendah \\
\hline 2 & Kesesuaian isi pelatihan terhadap bidang keahlian guru. & 97 & Rendah \\
\hline 3 & $\begin{array}{l}\text { Durasi lamanya waktu pelaksanaan pelatihan bidang } \\
\text { keahlian. }\end{array}$ & 84 & Rendah \\
\hline 4 & $\begin{array}{l}\text { Kesesuaian waktu pelaksanaan pelatihan bidang keahlian } \\
\text { dengan kebutuhan dan kondisi di lapangan. }\end{array}$ & 83 & Rendah \\
\hline 5 & $\begin{array}{l}\text { Kualitas penyelenggara program pelatihan bidang } \\
\text { keahlian. }\end{array}$ & 92 & Rendah \\
\hline 6 & Fasilitas pelatihan bidang keahlian. & 93 & Rendah \\
\hline 7 & Kesibukan di sekolah mengganggu proses pelatihan. & 72 & Tinggi \\
\hline 8 & Ketersediaan dana untuk mengikuti pelatihan. & 70 & Tinggi \\
\hline 9 & Motivasi guru mengikuti pelatihan bidang keahlian. & 88 & Rendah \\
\hline 10 & Kesibukan di luar sekolah mengganggu proses pelatihan. & 82 & Rendah \\
\hline 11 & $\begin{array}{l}\text { Kesempatan mendapatkan pelatihan melalui program } \\
\text { sekolah. }\end{array}$ & 69 & Tinggi \\
\hline 12 & $\begin{array}{l}\text { Kesempatan mendapatkan pelatihan melalui program } \\
\text { dinas atau pemerintah. }\end{array}$ & 60 & Tinggi \\
\hline 13 & $\begin{array}{l}\text { Kesempatan mendapatkan pelatihan melalui program yang } \\
\text { diselenggarakan oleh industri atau swasta. }\end{array}$ & 61 & Tinggi \\
\hline 14 & $\begin{array}{l}\text { Kesempatan mendapatkan pelatihan melalui program yang } \\
\text { diselenggarakan oleh perguruan tinggi. }\end{array}$ & 59 & Tinggi \\
\hline 15 & $\begin{array}{l}\text { Dorongan dari sekolah kepada guru untuk mengikuti } \\
\text { pelatihan bidang keahlian. }\end{array}$ & 81 & Rendah \\
\hline \multicolumn{2}{|r|}{ Rata-Rata } & 78.2 & Rendah \\
\hline
\end{tabular}




\section{SIMPULAN DAN SARAN}

Simpulan

Berdasarkan hasil pembahasan dapat ditarik beberapa kesimpulan diantaranya adalah sebagai berikut: (1) Terdapat 12 jenis penelitian bidang keahlian teknik otomotif yang diikuti oleh guru; (2) Dampak pelatihan bidang keahlian terhadap kemantapan kompetensi profesional guru masuk dalam kategori sangat baik; (3) Pelatihan yang paling diinginkan guru diantaranya adalah pelatihan (a) Electronic Fuel Injection (EFI) dengan persentase 70\%; (b) Teknologi Common Rail dengan persentase 87\%; (c) Electronic Power Steering (EPS) dengan persentase 67\%; (d) transmisi otomatis dengan persentase 77\%; (e) Sistem kelistrikan bodi dengan persentase $20 \%$. (4) Kendala dalam pelatihan bidang keahlian masuk dalam kategori rendah, namun masih terdapat aspek yang memiliki tingkat kendala yang tinggi.

Saran

Berdasarkan simpulan dapat diajukan saran sebagai berikut: (1) Bagi Dinas Pendidikan, menetapkan kebijakan pembinaan guru khususnya bidang studi melalui pelatihan terintegrasi berbasis kompetensi. Di samping itu, diterapkannya kebijakan secara tegas sesuai peraturan perundangan yang berlaku; (2) Bagi SMK, dilakukan pembinaan sesuai kebutuhan kompetensi guru; pemberian tugas dan tanggungjawab yang proporsional; dan penerapan kebijakan yang didasarkan peraturan yang ada; (3) Bagi Guru, melaksanakan pelatihan secara aktif dan mandiri serta banyak melakukan magang atau Praktik Industri (PI) sesuai kebutuhan.

\section{DAFTAR PUSTAKA}

Anonim. (t.th.) . Menuju ASEAN Economic Community. Jakarta: Departemen Perdagangan RI

Depdiknas, Undang-undang No 14 Tahun 2005, tentang Guru dan Dosen.
Permendiknas Nomor 16 Tahun 2007, tentang Standar Kualifikasi Akademik dan Kompetensi Guru

Jacobs, Ronald L. (2003). Structured On-theJob Training: Unleashing Employee Expertise in the Workplace. San Francisco: Barret-Koehler Publishers, Inc,

Mardapi, D. (2008). Teknik penyusunan instrumen tes dan nontes. Yogyakarta: Mitra Cendikia Offset.

McAshan, H.H. (1979). Competency-based Education and Behavioral Objectives. Englewoods Cliffs: Educational Technology Publications, Inc.

Suyanto. (2007). Tantangan Profesional Guru di Era Global. Pidato Dies Natalis ke-43 Universitas Negeri Yogyakarta. 21 Mei 2007.

Wirawan. (2002). Profesi dan Standar Evaluasi. Jakarta: UHAMKA PRESS. 